Review Article

\title{
Spurious drugs: do we neglect during our clinical practice? a systematic review
}

\author{
E. Manivannan, V. Sivasankari*
}

Professor, Department of Pharmacology, Vinayaka Mission's Medical College, Vinayaka Mission's University, Salem, Tamilnadu, India

Received: 06 October 2016 Accepted: 03 November 2016

\section{*Correspondence to: \\ Dr. V. Sivasankari, \\ Email: drvsivasankari@ gmail.com}

Copyright: (C) the author(s), publisher and licensee Medip Academy. This is an openaccess article distributed under the terms of the Creative Commons Attribution NonCommercial License, which permits unrestricted noncommercial use, distribution, and reproduction in any medium, provided the original work is properly cited.

\begin{abstract}
Spurious drugs are those manufactured by concealing the identity of the true ones. It forms one of the largest growing markets in India. The aim of this review is to create an awareness of the prescribing doctors that substandard or fraudulent drugs are widely prevalent and it is in our doorstep during the regular practice. The duty of the prescriber is to identify these drugs, share the information's to the fellow colleagues and avoid them from prescribing. It is the role of the physicians to intimate this information to the patients also who consumes these drugs due to lack of awareness as like food products which are consumed as an adulterant one. We the health care professionals carry the duty of identifying these spurious drugs being manufactured and marketed by unlicensed or licensed pharmaceutical companies which are hazardous to our patient's health. All the data's about this misbranded drugs are gathered from Journals and related websites from 2000-2016, thereby complied to reveal the present situation of spurious drugs. The Government of India has taken steps to implement Cosmetics Act 1940 and special courts are set up for speedy disposal of these related cases. Also the Government in its part announced the "Whistle Blower Scheme" to encourage the public to be vigilant and report the widespread infiltration of spurious drugs in the market and to receive the cash reward for this information.
\end{abstract}

Keywords: Cosmetics Act 1940, Fraudulent drug, Spurious drugs, Whistle blower scheme

\section{INTRODUCTION}

Spurious drugs are defined as per Drug and Cosmetic Drugs Act, 1940 as imitation drugs which resembles another drug or substituting the whole or a part of that drug. It may range from inactive drugs to falsely labeled drugs, whereby concealing the true identity of the drug. ${ }^{1}$

Consumption of spurious drugs leads to deterioration of health and marked adverse consequence to the patients mainly general public who are unaware about these drugs. ${ }^{2}$ The incidence of spurious drugs as per Drug Controller of India verified with the percentage of around $0.3 \%$ while the media magnifies it to be around $10-25 \%$. Mr. Srinivasan in his article stated that the expired drugs are recycled and reused. ${ }^{3}$ Manufacturing of unscientific fixed dose combinations are very common in small companies throughout India. A study by Jan swasthya mentioned that $60 \%$ of the top selling drugs in the ORG-
IMS-Nielson list are irrational. ${ }^{4}$ The common man without knowing the purity and quality of the drug, consumes and spoil his health which is more hazardous than the disease process itself.

The Drug and Cosmetic Act pointed out any drug which is found to be spurious, misbranded seeks the penalty under the section 18 and 27. Also the recent amendments of the Drug and Cosmetic Act allows a heavy fine and imprisonment of 10 years or 3 times the value of confisticated good. ${ }^{1}$ The recommendations of Dr. Mashelker committee specifies that spurious drugs comes under non-available, cognizable offence and recommending the maximum penalty of death for this offence. $^{5}$

Drug manufacturer's compliance regarding the quality of the drug products is monitored by US FDA. The current Good Manufacturing Practice regulates the drugs 
manufacturing, processing and packing of a drug product. India's Central Drug Standard Control Organization [CDSCO] has started training Indian drug manufacturers to meet UDFDA'S manufacturing practice. ${ }^{6}$

Mr. G. N. Singh Drug controller General of India heading CDSCO has remarked that Andhra Pradesh and Karnataka shows a better adherence to manufacturing practice when compared to Bihar and Uttar Pradhesh. ${ }^{7} \mathrm{He}$ added that most of manufacturers are not aware of national and International Standards of manufacturing. This is one of the reason why spurious drugs or substandard drugs are being manufactured. He also quoted that Indian Government is following methods of Medicine and Healthcare Products Regulatory Agency [MHRA] differently in comparison to the USFDA.

The whistle blower policy framed by the Government of India under the Health and Family Welfare rewards the informer who manufactures and distributes, spurious drugs. ${ }^{8}$

Explanation by the Indian drug manufacturer's association states that some premotivated news which is manipulated by foreign drug manufactures there by damaging the reputation of Indian domestic manufacturers.

\section{ROLE OF PHYSCIANS IN THE SOCIETY}

The role of the physicians is to educate their patients about the indications, probable side effects of a prescribed medication. Apart from this he should audit that prescribed drug should not be replaced nor duplicated by the pharmacists and retailers. Generally physicians review medications at each visit, should also ensures that the particular company products which he prescribes is consumed by the patients.

The prescriber should know about the existence of fraudulent drugs and its consequences on the patient's health. It is difficult for the doctors to know the profile of the upcoming marketed drugs, its consequences on the ill health of the patients. Health care professional should concern more about the prescribed brand names and verify the list of approved drugs released by CDSCO. ${ }^{9}$ Recently in March 2016, the Doctors body asked the government to check the menace of spurious drugs in Jammu and Kashmir valley. ${ }^{10,11}$ According to an article published in BMI 2002, the author provided some tips in a way that fake drugs possess poorly printed covers, fake medicines doesn't contain the batch number, manufacturing date and expiring date. Also Brittle tablets and uneven coating of the tablets, chipping, discoloration adds to the same list. The presence of fungus growth, lump formation, and addition of non-permissible colors in liquid preparation also found to be fake. ${ }^{12}$
OM Prakash Seth, President of Delhi pharmaceutical Dealer's association points out "distributors has increased to a strength 693 from 198 in $1997 .{ }^{13}$

The state wise data reveals that more suspects was found in Bihar followed by Gujarat, west Bengal, Rajasthan and Maharashtra. This information is in form of news and media reports except 2 National studies done by SEAR pharm forum in 2007 and second study in 2009 by Drug Regulators of India at CDSCO. When treatment fails, the prescriber should consider that spurious medicines would be the cause. ${ }^{14,15}$

The physician should follow the provisions of state act like Drugs and Cosmetic act 1940, Pharmacy Act 1948 and other acts for optimum protection and promotion of public health. For those doctors who purchase and dispense medications, they do have the responsibility to avoid any infiltration of spurious medicines with a legitimate food chain. They should know the facility to return expired or damaged drugs to $\mathrm{C}$ and $\mathrm{F}$ agents of the manufacturing companies which is not followed in India as recommended by CDSCO unlike Western countries. ${ }^{16}$

On the prescriber's side, it is difficult to identify the misbranded drugs as a lot of pharmaceutical representatives convince the doctors to prescribe their medications. The doctor cannot go to websites everyday for checking the genunity of the drug which is outpouring every day. It is a general belief that branded MNC's would offer them a quality drug rather than the unknown new pharmaceutical company. Dr.Kamath, a medicolegal consultant and honorary secretary of Mumbai's consumer Guidance Society of India points out that genuine drug will have proper seal, print and holograms. We go by the wording that known details branded drug company products is better than the new unknown Angel's company drug unless otherwise the new companies has to satisfy the prescriber about their companies R\&D and prove the genuninity of their products.

\section{CONCLUSION}

Mr. Dinesh Thakur, the Ranbaxy Whistle blower staging a lonely battle against these spurious drugs in India. The CDSCO has created the "Drug Alert System" to contain this problem. Doctors know inflow of new companies' everyday with their own brands. A simple question is do we accept all marketing representatives of pharmacy companies promotes their products for their personal gain without having much social responsibility for their citizens. Hence doctors on their part should take extra burden to check the true identity of the drugs, quality of packing, labelling, and report to the state regulatory authority when they come across spurious drugs by updating the knowledge in this branch. Prescribers should involve them along with government and nongovernment organizations in the detection and prevention of counterfeit drugs. 
Funding: No funding sources

Conflict of interest: None declared

Ethical approval: Not required

\section{REFERENCES}

1. Ministry of Health and Family Welfare; 2005. [Last cited on 2014 Oct 14] Government of India, Drugs and Cosmetic Rules (Amendment) Available from: http://www.cdsco.inc.in./forms/contentpage 1.aspx? Lid $=1888$.

2. New Delhi: Ministry of Health and Family Welfare, Government of India; 2009. [Last cited on 2013 Nov 20]. CSDCCO. Report on countrywide survey for spurious drugs; pp. 3-4. Available from: http://www.cdsco.nic.in/report_book_13-7-10.pdf.

3. Srinivasan S. Indian Journal of Medical Ethics. 2010;7(3).

4. India: All India Drug Action Network 2014 posted on August 20, 2014. Towards a people oriented, rational drug policy.https//aidain.india.word press.com.

5. Sagar BPS, Zafar R, Singh A. Counterfeit, Fake, Spurious drugs. Health Administrator. 2006;1:55-73.

6. Drug and Cosmetic Act available at http://www.cdsco.nic.in/forms/contentpage1.aspx?lid=1 888 th (Latest access: 09 October 2014).

7. Central Drugs Standard Control Organization (Directorate General of Health services) Ministry of \& Family Welfare, Chandigarh - Details of Samples tested during the last 3-financial years in all 7- Drug Testing Laboratories of CDSCO. Available at: the http://www.cdsco.nic.in/writereaddata/lab\%20data.pdf (Latest access: 09 October 2014)

8. Ministry of Health \& Family Welfare - Reward Scheme for Whistle blowers in the fight against the menace of spurious or fake drugs, cosmetics and medical devices. Available

at: the
http://www.cdsco.nic.in/writereaddata/Whistle\%20Blow er\%20Scheme.pdf (Latest access: 09 October 2014)

9. CDSCO Ministry of Health and Family Welfare [last updated on 1.1.2016] Government of India. Available from www.cdsco.nic.in/forms/list.aspx?lid.

10. India: Daily Excelsior. Com. 2013 [Last cited on 2016. Available from.www.dailyexcelsior.com/230084spurious drugs consumed by the patients in JK.

11. Dutta N. Kashmir fake drug scam: were spurious drugs responsible for high infant deaths last year? 2013 [Last cited on 2013 Apr24]. Available from:htpp://www.health.india.com/news/Kashmir-fakedrug-scam-were-spurious drugs responsible-for-highinfant-deaths-last-year/.

12. Drug control. Spurious drug News. 2013. [Last cited on 2013 march 5]. Available from http://www.drugscontrol.org/spurious drugs.htm.

13. Chatterjee P. India's trade in fake drugs-bringing the counterfeiter's to book" Lancet. 2001;357(9270).

14. Khan AH, Khar RK. Current scenario of spurious and substandard medicines in India. Generic Medicines. Press information Bureau of India; 2012. [Last cited on 2013 Jan 8] PIB, Available from: http://www.pib.nic.in/newsite/erelease.aspx?relid= 83323.

15. Initiatives, Achievements and Targets Central Drugs Standard Control Organization (2001 - 2020) http://www.cdsco.nic.in/writereaddata/CDSCO\%20Initi atives $\% 20 \& \% 20$ th Targets\%20for\%20website $\% 2013$ 7-2012_17-07-2012.pdf (Latest access: 09 October 2014)

16. New Delhi: CDSCO report 2008 [Last cited on 2013 Oct Nov 13]Guidelines for taking action on samples of drugs declared spurious or not of standard quality the light of enhanced penalties under The Drug and Cosmetic (Amendment) Act;pp.1-13. Available from: http://www.cdsco.nic.in/writereaddata/Guidelines under new penal provisions 9 .pdf.

Cite this article as: Manivannan E, Sivasankari V. Spurious drugs: do we neglect during our clinical practice? a systematic review. Int J Basic Clin Pharmacol 2016;5:2308-10. 